\title{
21 \\ THE INTERSECTIONS OF SMUGGLING FLOWS
}

\author{
Annette Idler
}

\section{Introduction}

Across the world, trafficking routes are used for multiple types of goods in various directions. In Libya, people, arms, drugs, and contraband are smuggled on the same routes, in Myanmar, both human trafficking and drug trafficking takes place across the border to Thailand and China at the same crossings, and in Colombia, cocaine is shipped abroad via Venezuela and on that same route gasoline is smuggled from Venezuela into Colombia. To account for this interconnectedness, this chapter conceptualizes smuggling flows as illicit supply chain networks. These networks comprise multiple interconnected forms of transnational organized crime, ranging from the illicit drug trade through arms, human, and wildlife trafficking, to financial flows stemming from money laundering essential to all these forms of organized crime. Of course, not all forms of transnational organized crime have the same underlying logics. In the case of human trafficking, for example, the victims of the crime are not only those who may be forced to help traffickers, or those who are targeted because they are in the traffickers' way, but also the very people that are being trafficked (see, e.g., Chapkis 2003). Similarly, the dimension of illegality varies. Gasoline or oil, for example, in themselves are not illegal, but the practice of smuggling them is. Cocaine, on the other hand, unless for medical use, is illegal in most circumstances already - regardless of whether it is trafficked across borders or not. Still, across these different logics, the networked character largely remains the same: it connects victimless with other types of transnational organized crime, smuggling flows of household goods with those of illicitly used goods, or of people, and local petty smugglers with large-scale global trafficking rings.

The networks include strategic trafficking nodes, that is, illicit business hubs and starting points of international trafficking routes where various illicit flows converge. These intersections are the places where unscrupulous entrepreneurs, such as criminals, rebels, or corrupt military officials, meet to strike business deals. Rivalry over economic profit among these actors entails selective violence against potential and actual betrayers. Demonstrating the relevance of these trafficking nodes in the context of four analytical dimensions of illicit supply chain networks - the input-output structure, the institutional context, territoriality, and the governance structure - this chapter calls for moving beyond the study of individual flows in isolation. It suggests focusing both scholarly and policy attention on the interconnectedness of legally and 
illegally used routes in order to grasp the social, economic, and political repercussions on the localities in which the flows are embedded and the people who inhabit them.

In what follows, I briefly contextualize the interconnectedness of illicit flows historically. Subsequently, I conceptualize illicit supply chain networks and demonstrate how and why analyzing the intersections of trafficking flows is important to enhance our overall understanding of the illicit economy and its link to instability.

\section{The interconnectedness of illicit flows in historical perspective}

Illegal economic cross-border movements are historic (Friman and Andreas 1999, 1). According to Manuel Castells (2010, 172), "Crime is as old as humankind. Indeed, in the biblical account of our origins, our plight began with the illegal traffic of apples." State formation goes back to illicit flows, as Charles Tilly (1985) showed on European states, and Peter Andreas (2014) on the United States, the "smuggler nation." Likewise, the interconnectedness and multidirectional nature of illicit flows is nothing new. Syria, for example, has long been a transit point for drugs originating from Europe, Turkey, and Lebanon and destined for Jordan, Iraq, and the Persian Gulf. Local cross-border tribes and groups have engaged in trafficking livestock and consumer goods (and to a limited extent, drugs) between Syria and its neighbours since the inception of the state after the fall of the Ottoman Empire. The region also features a longstanding tradition of looting and antiquity smuggling from archaeological sites.

Nonetheless, the interconnectedness of illicit flows, that is, "flows of illicitly used goods or money, or of trafficked people" (Idler 2020, 336), ${ }^{1}$ has taken on new forms, characterized by a global network of transactions and exchanges that occur in an ever accelerating speed.

How did we get there? The end of the Cold War entailed a proliferation of states with highly fragile regions and of what some considered "failed states" - convenient hubs for traffickers to operate from (Naím 2007, 26). In countries where state capacities are weak, especially at the geographical margins, borders are hard to control and officials are easily corrupted (Naím $2007,29)$. These locations thus become destinations or starting points of individual flows and especially if they are geostrategically significant - hubs connecting various flows that both enter and leave the country. Nigeria, for example, has turned into a trading hub for heroin from the Middle East to Europe and North America, as well as for ivory and rhino horn trafficking. Similarly, Haiti has become a major transit zone for cocaine trafficked from South America into the US, while also witnessing human trafficking from Haiti into the Dominican Republic.

The Cold War's end, together with the acceleration of globalization in the 1990s, also brought about important changes in the global economy. When the Iron Curtain fell in 1991, both licit and illicit trade expanded across states formerly belonging to the East and West blocs respectively. These economic activities benefitted from more interdependent and expanded markets, fewer border checks, and the privatization of state property in the former East bloc, including military hardware. Economic liberalization and increased financial mobility in an increasingly globalized world further consolidated the interconnectedness of different illicit flows (Andreas 2003; see also Lexico Oxford Dictionary 2020). Enhanced communication and information technologies as well as transportation infrastructures in the 1990s expanded the networks of flows that came to span entire continents. Global illicit networks transformed into less centralized webs of transactions (Naím 2007, 227): just as in the global licit economy, where companies source, formulate, and assemble globally, smugglers exchange and enhance illicit products globally. Financial liberalization allowed smugglers to make their transactions less traceable than ever before. Smugglers can break down large cashless financial flows into 
different parts with different networks financing each part, sometimes without knowing who else is involved.

In the first two decades of the twenty-first century, the pace at which information spreads accelerated further, which contributed, in part, to three trends that favour the interconnectedness of illicit flows. First, violent non-state groups have proliferated with more new groups having formed in the past ten years or so than over the past six decades together. Second, these groups operate increasingly transnationally. At its height, the so-called Islamic State (IS), for example, declared provinces in ten different countries. Third, relatively easy and instant access to information has changed patterns of mobilization, propaganda, and recruitment with social media quickly reaching individuals far away from the physical location of the respective group. These trends have boosted the interconnectedness of illicit flows because they facilitate dynamic links among groups: in Syria and neighbouring countries, those labelled terrorists such as IS engage in spot sales with arms or ammunition dealers (Solomon 2015); in the Central Mediterranean, human smugglers work with Libyan militias (Micallef and Reitano 2017); in South America, left-wing guerrillas cooperate with Mexican drug cartels (Idler 2019); and, globally, organized criminals subcontract hackers (EUROPOL 2018, 15-24). Overall, through these developments, the scope of the activities belonging to the "Other Side of Globalization" (Abraham and Schendel 2005, 4) has expanded: global networks supersede local smugglers, common criminals join transnational terrorists, and chains of illegal drug, human, or weapons trafficking expand past regions to extend across continents (Deville 2013, 63).

State regulation, law enforcement, and political awareness of illegal economic cross-border activities have changed also (Andreas 2009, 15). Realists stress borders' function of delineating territorial sovereignty, and globalists argue that growing global interdependence has made borders progressively less relevant due to a continuing de-territorialization (Brenner 1999, 60-67) that has led to a "borderless world" (Ōmae 1990). Accordingly, globalization would have transformed borders into "bridges for commercial transactions rather than economic barriers and fortified military lines" (Andreas 2003, 83). However, analyzing the interconnectedness of illicit flows confirms that, rather, "geopolitics is transformed, not transcended” (Andreas 2003, 108). As Clunan and Trinkunas (2010, 9) put it, “asymmetries in states' taxation and regulation in a world of globalized demand create the incentives for engaging in 'jurisdictional arbitrage' in the form of smuggling and trafficking." While border controls have become stricter through sophisticated intelligence and surveillance technologies, these same technologies enable those who evade the law to circumvent controls and adapt to changing market conditions. More border control to curb such activities may be counterproductive: the greater the risk associated with the illegal enterprise, the higher the profits and hence the incentives to engage in it (Schendel 2005, 59).

Against this backdrop, illicit entrepreneurs take advantage of the bureaucratic constraints, if not inertia, of law enforcement authorities to benefit from new technologies. They quietly expand and consolidate global illicit supply chain networks that slowly pervade the entire international system, comprising both state and non-state actors such as non-governmental organizations or the private sector with the international community hardly noticing it. The transformative power of online illicit marketplaces, also called cryptomarkets, illustrates this well. The now defunct Silk Road for example, a website that operated on an encrypted part of the internet, the TOR network, also known as the "Dark Net" or "Dark Web," used to facilitate the illicit trade of drugs (Martin 2014; see also Lusthaus 2013). Both buyers and sellers benefitted from anonymity provided by this "cyber-assisted" crime. ${ }^{2}$ By facilitating direct online exchange, global networks become more efficient and harder to trace as intermediaries and traffickers at times become superfluous. These are the actors that may resort to violence to 
achieve their ends, hence the decrease in physical transactions can also lower the chance of spectacular violence. While this may seem a positive "side-effect," the consequence is also concerning: being increasingly managed and controlled in non-physical space, these illicit supply chain networks have the potential to erode the international system from within by penetrating its structures without triggering violent conflict that would alert the system's defenders (Idler 2017).

The complexity of these illicit operations makes them less noticeable to the international community than large geopolitical shocks, but in no way less significant. From the corruption of state officials and others due to the lack of control mechanisms to the alienation of communities from central states as a result, the possibility of shifting operations to cyberspace has opened opportunities to actors involved in interconnected illicit flows that we are only beginning to understand.

\section{Illicit supply chain networks - the intersections of illicit flows}

Drawing on Idler (2020, 339-42), I now conceptualize interconnected illicit flows as illicit supply chain networks (Deville 2013, 65). ${ }^{3}$ A "supply chain, a complex network of organizations and facilities which are mostly settled in a vast geographical area or even the globe, synchronizes a series of interrelated activities through the network" (Govindan, Fattahi, and Keyvanshokooh 2017, 119; see also Christopher 1998). Supply chain networks are commonly analyzed along four dimensions: (i) input-output structure; (ii) territoriality; (iii) institutional context; and (iii) governance structure (Gereffi and Korzeniewicz 1994; Bair 2005). As I show with examples from across the globe, analyzing illicit supply chain networks along these four dimensions sheds light on the nature and implications of the intersections of illicit flows.

\section{i Input-output structure}

Illicit supply chain networks that concern goods that need to be processed (as opposed to flows of people for example) can be analyzed according to their input-output structure. "A [supply chain] network converts raw materials into final products and then delivers them to customers. It includes various types of facilities, and each type plays a specific task in the network" (Govindan, Fattahi, and Keyvanshokooh 2017, 112). Given that various illicit supply chains are interconnected, this process manifests a networked character. ${ }^{4}$

In the illicit supply chain networks of cocaine or heroin, for example, the main supply chain begins with production activities: resource extraction (that is, coca or opium poppy cultivation and harvesting), and the processing of the raw material into the final product (processing coca leaves into coca paste and coca paste into cocaine, or processing opium poppy into opium, then morphine, and then heroin). The supply chain continues with three further interrelated activities: the actors involved transport the good domestically, traffic it internationally, and distribute it in markets. This supply chain intersects with supply chains of goods that are added to process the raw material into the final product, including gasoline (in the case of cocaine production) and chemical precursors (such as acetic anhydride to process morphine into heroin) (European Monitoring Centre for Drugs and Drug Addiction and Europol 2019).

The flow of cocaine, heroin, or any other illicitly produced good intersects with flows of other goods. Illicitly used drugs are, for example, exchanged in as drugs-for-arms deals. Such barter agreements have included small and light arms but also advanced military-grade weapons such as surface-to-air missiles (European Monitoring Centre for Drugs and Drug Addiction and Europol 2019). Other types of barter agreements involve ammunitions, counterfeit medicines, 
or humans; for example, kidnapped hostages or trafficked people may be exchanged for illicit goods through barter agreements. Criminals and other violent non-state groups often strike such business deals via intermediaries. These illicit flows intersects with flows of money (profits from sales of the illicitly produced goods) that the groups launder to redirect it into the licit economy (see e.g., Abraham and Schendel, 2005; Deville 2013). These intersections form the nodes of the trafficking routes. On the market side, international traffickers typically liaise with local dealers who distribute the illicit good among consumers or other types of clients.

Figure 21.1 illustrates the illicit supply chain networks.

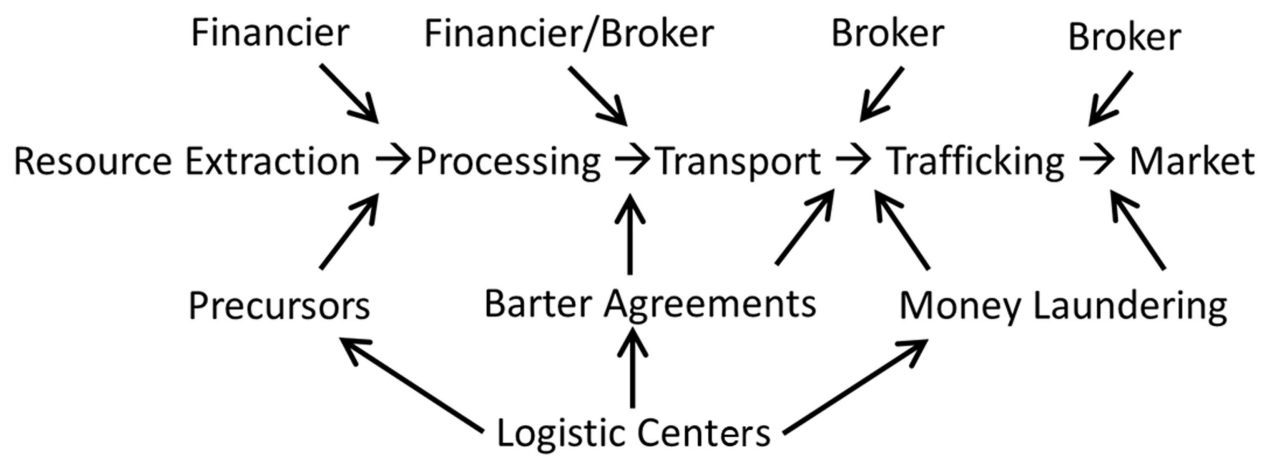

Figure 21.1 Illicit supply chain networks

Analyzing illicit supply chain networks in line with their input-output structure sheds light on the expertise that is necessary to coordinate and connect various flows. The police commander of a Colombian town in a region highly affected by cocaine trafficking and interconnected flows of gasoline, arms, people, and chemical precursors described this the following way to me during one of my fieldwork trips to the region:

We often hear about the term "route." Delinquents even sell routes. In the criminal sphere, when they say that the Rastrojos [a Colombian right-wing violent non-state group] sell a route, what they really sell is the logistics chain of the business. This includes the know-know, information on how it works, and who is involved. They say: 'Look, I know who is producing, who has land to produce coca. I know how the precursors enter this sector and I have the contact. I know where the laboratories are and who is able to process the coca leaves into coca base and then the coca base into cocaine. It includes the entire procedure. I know where we can store the cocaine. I know with whom and where we can take it out of the country and what means of transport we can use, and I know who will receive it abroad, in Spain or in the US, or in other export countries. And I know how we can transport the money because I have the necessary contacts for that.' This is a route. ${ }^{5}$

Understanding and, ultimately, addressing intersecting smuggling flows, thus starts with grasping the expertise involved in this illicit enterprise, rather than only tracing its physical expressions. The same expertise is often used for various types of flows that operate on the same routes. In the Colombian context, cocaine, gasoline, chemical precursors, money, weapons, and people are linked to the same input-output structure; in Libya, drugs, arms, people, and contraband share the same routes; and in Mali, flows of cigarettes, arms, and drugs interlink. 
Such routes are not limited to single countries or regions. In 2018, a case spanning South America, Europe, and West Africa made headlines: a Colombian broker, facilitating cocaine trafficking from South America to the European Union via West Africa, intended to exchange the drugs in a barter agreement with advanced military-grade weapons, including surface-to-air missiles. These weapons were supposedly destined for the militant Islamic group Ansar al-Dine operating in Mali. Given Ansar al-Dine's links with al-Qaeda, this should have allowed the Colombians to use routes passing through al-Qaeda controlled territory in the Sahara Desert. The cocaine-weapons exchange was planned to occur in Croatia. This is not unusual: Colombian traffickers are known to buy protection for their drug shipments from armed actors who control the land routes from West Africa to Europe in the form of drugs, money, or weapons (The Investigative Project on Terrorism 2018; European Monitoring Centre for Drugs and Drug Addiction and Europol 2019, 42; Katersky 2019).

\section{ii Territoriality}

The spatial distribution of supply chain networks entails its territoriality. ${ }^{6}$ Each locality has a specific function, or role, within the networks. For example, coca or opium poppy cultivation and laboratories are located on production sites of these illicit supply chain networks. Illicit flows intersect and converge in strategic towns, villages, or harbours. These localities function as strategic trafficking nodes, where physical transactions take place or where these transactions are coordinated in logistic centers. They also include starting points of international trafficking routes.

Understanding historical legal trading patterns helps identify the locations where illicit flows intersect. Often, trafficking nodes or starting points of international trafficking routes have been, or still are, trade hubs for legal commerce due to their strategic location. In Libya for example, arms and drugs are trafficked via routes that have been used historically for transporting legal products. Consider Libya's regional capital of Sebha, located in the south west of the country, and known for its historical function in trans-Saharan trade as a strategic node. Three historic trade routes converge in Sebha: first, the route that starts in Algeria and continues to the East; second, the route that begins in Niger and extends to the south; and third, the route that begins in Libya's southern neighbour Chad. It is also located near the Sharara oil field, which further adds economic importance to the town. This position makes it prone to being a hub where illicit trade routes connect too and hence violent non-state groups, such as the Misuratan militias, take interest in controlling the town (Reitano and Shaw 2017).

Geostrategic locations can also impede legal commerce when illicit flows are historic and precede appropriate institutional state presence. The towns of Tumaco and Buenaventura at Colombia's Pacific coast, for instance, are important starting points of international trafficking routes. In Tumaco, numerous different violent non-state groups are present, aiming to get a share of the profit made from cocaine trafficking, gasoline smuggling, and related forms of trafficking. These groups have ranged from the Revolutionary Armed Forces of ColombiaPeople's Army (FARC-EP) and the National Liberation Army (ELN) as well as the FARCEP's successor groups, to paramilitary groups and their successors, and Mexican drug cartels (Idler 2019, 180-194). Even though both Tumaco and Buenaventura have the potential to be important legal trading hubs because of their location, the lack of state infrastructure, high militarization, and endemic corruption pose severe obstacles to fulfilling this potential.

These examples - Sebha, Tumaco, and Buenaventura - are trafficking nodes of intersecting flows at the local level, but, due to their geostrategic location, also entire regions are prone to being hubs of various types of illicit flows. Referring to flows of illicitly used drugs, Philip 
Robins (2021) calls this "narco-geography." The Middle East, for example, is a recipient of Afghan heroin via Pakistan or Iran; cocaine from the Andean region enters via Brazil; and tramadol (non-medical use of pharmaceutical opioids) comes from China and India (UNODC 2018). Understanding how these flows converge in a single region and where routes - not only in the physical sense, but also in terms of the necessary expertise as discussed above - are shared is an important first step to disrupt them.

Even though over longer periods illicit supply chain networks may shift geographically, from a short-term perspective, the locations for most of the supply chain functions prior to international trafficking are relatively exogenous if they involve natural resources. Coca or opium poppy cultivation, for example, requires adequate climatic conditions, and other raw materials such as gold, diamonds, or coltan are only found in certain regions. Thus, resource extraction sites are relatively fixed. Likewise, laboratories used to process raw materials into the final product are predominantly located in proximity to cultivation or extraction sites. ${ }^{7}$ Domestic transport depends on adequate transport infrastructure such as fluvial systems or roads. To some extent, the locations of strategic nodes are also exogenous. Starting points of international routes are located in harbours, or border towns, where illicit goods are shipped abroad.

Intersecting flows of chemical precursors, for instance, typically come from countries where these products are cheaper; weapon flows connect with countries suffering armed conflict or other forms of instability since these weapons sustain the fighting of (non-state) armed groups. Money flows connect with countries whose currency is convenient for money laundering. This is exemplified by money flows from Colombia deriving from the cocaine industry into the dollarized Ecuadorian economy. These last two examples indicate the relevance of demand or convenience in determining the market end of illicit flows; that is, their direction, as part of the territoriality of illicit supply chain networks. The existence of consumers who can afford relatively pricey drugs such as cocaine, as is the case in the United States and in Western Europe, likewise influence the direction of drug flows.

Drug policies and local cultures also inform the territoriality of illicit supply chain networks, including the transit countries. A common cocaine route from South America to Europe transits West Africa, where corruption of state officials facilitates the business. Impunity and inefficient drug policies have also led to a situation in which the region is increasingly becoming a consumption market, in addition to its function as transit zone (Pokoo and Aning 2021). A similar dynamic can be observed in North Africa (27-33 Herbert and Gallien 2020). Flows of human smuggling typically lead from unstable regions into more industrialized regions, whereas illicit flows of, for instance, toxic waste can be traced in the opposite direction: from wasteproducing industrialized countries into unstable regions with weak state governance where the waste can be dumped while those in charge remain in impunity (Hägerdal 2019; Andreatta and Favarin 2020).

Illicit supply chain networks operate in physical and non-physical spaces concurrently, with the latter gaining traction. If in the "upperworld," novel technologies have shrunk geography by making the world more connected, in the "underworld," they have allowed illegal actors to side-line geography entirely. In the process of globalization, way stations along trafficking routes have partly moved into cyberspace (Naím 2007), complicating the territoriality of illicit supply chain networks. Warehouses often exist online, which reduces risks because participants in the illicit chains do not meet each other. Internet-based spot sales and barter agreements of drugs, slaves, or weapons, to name just a few "products" in places such as the Dark Web, as mentioned above, and remotely controlled shipments are examples where it may be difficult to determine the territoriality of these flows. Services like TOR do not exist in any particular physical location and yet enable transactions across the globe. As a side-effect of the ability of 
decentralized networked actors to circumvent laws and regulations, these actors can enhance their comparative advantage of being flexible and resilient to external shocks even more in the non-physical space, while those abiding by the rules are likely, increasingly, to lag behind. At the same time, transactions in cyberspace also help expand and foster territorial, physical networks of flows across borders (Prince 2016). The territorial aspect in physical space thus remains significant and has important social, economic, and political implications, especially in the trafficking nodes where various flows intersect.

\section{iii Institutional context}

Typically, weak state governance systems characterize the institutional context of illicit supply chain networks. ${ }^{8}$ In many marginalized areas in unstable regions, state representatives are absent. In such contexts, local populations have few legal economic opportunities to sustain their livelihoods. The income that people can gain thanks to various intersecting illicit flows in these regions would not be available otherwise. Even though most of the time, generating income this way is illegal, local community members consider it legitimate. People's involvement can take various forms. First, they participate directly in forms of smuggling. This includes "survival smuggling" of essentials such as food on the one hand, and of illicit commodities on the other (United Nations and World Bank 2018, 70). Survival smuggling is practiced across the globe, ranging from nomadic communities in the Sahel to the indigenous Wayúu across the Colombia-Venezuela border. These forms are typically unconnected from other types of illicit flows.

Second, local community members smuggle goods that are used for daily consumption and are part of illicit supply chain networks. Take the gasoline smuggling across the ColombiaVenezuela border. Given that the Venezuelan government used to subsidize gasoline, Colombians and Venezuelans had been smuggling gasoline from Venezuela into Colombia for decades to sell it openly on the streets. Local law enforcement authorities were aware of the illicit practice, but since it was so wide-spread - and alternative economic opportunities were lacking - efforts to tackle it were sparse. At least until the early 2010s, before Venezuela further descended into a downward spiral of political and socio-economic crisis, ${ }^{9}$ three types of smuggling were common: the small-scale one of a few litres; the medium one that fills car tanks; and the large-scale one in which entire trucks were filled with gasoline (Idler 2019, 169-174). This third type directly connected with cocaine trafficking in two ways. First, the gasoline was used to process coca leaves into cocaine, as part of the input-output structure. Second, it formed part of gasoline-drugs deals: the same trucks that transported gasoline from Venezuela to Colombia transported cocaine in the opposite direction. As in other smuggling hotspots around the world (see, e.g., Gallien 2020), such deals were highly regulated through informal arrangements, involving the local population. In places such as $\mathrm{La} \mathrm{Paz}$, in the Colombian Cesar department, where the gasoline was taken off the trucks, locals for example were (ab)used to help with storage. They had to give their houses or garages, for example, to stockpile the gasoline. They were paid in return, and hence this practice helped them feed their families, but, at the same time, denying their service exposed them to threats of violence and the implementation thereof, as a report by the local Ombudsman's Office confirms (SAT, Sistema de Alertas Tempranas. Defensoría del Pueblo de Colombia 2012). Furthermore, the small-, medium-, and large-scale types of smuggling were closely interlinked. Even if small-scale smugglers, so-called pimpineros, were not directly involved in large-scale forms of trafficking, they typically had to pay "taxes" to the violent non-state group that controlled the route for the purpose of large-scale trafficking. This put these smugglers into an extremely vulnerable 
position: they suffered abuse by the armed actors yet could not turn to the local authorities for help as they themselves were involved in an illegal business.

Gasoline smuggling across the Ecuador-Colombia border is another case in point. Local community members used to smuggle gasoline from Ecuador to Colombia for their vehicles and boats. Even though illegal, they considered smuggling legitimate because alternative livelihood options were scarce. When the Ecuadorian authorities imposed stricter rules and limited the volume of gasoline that can be trafficked per day, the income of many contrabandists no longer sufficed to cover their daily expenses. Furthermore, it led to human rights abuses against those small-scale traffickers by the local authorities while large-scale traffickers linked to the cocaine industry continued business as usual (Idler 2021). As shown in these examples, addressing the links among different types of illicit flows needs to be based on analyzing the transnational political economy of a region, and indeed its moral economy (Arias and Grisaffi 2021).

Syria's oil smuggling business is a similar example. Syrian rebels used to sell a barrel of oil for up to 22 US dollars. Those involved in refining earned 30 cents for each litre of gasoline that was sold. Just as the community members in La Paz that were connected to gasoline smuggling by helping stockpile the product, in Syria, community members were also involved in related forms of business. This included transport and services, such as repairing engines damaged by the fuel of low quality, offering food, fuel, and other goods to smugglers along the road, or helping truckers fit large tanks to their vehicles (Steenkamp 2017). Likewise, one can distinguish among different forms of smuggling. On the one hand, the small-scale form originates in small oil fields controlled by local tribal chiefs who control extraction. The oil is then transported across territories controlled by local militias who charge taxes or protect - against payment - basic refineries. On the other hand, large-scale smuggling has been controlled by more powerful and violent non-state groups, especially IS. The group controlled around $8 \%$ of Syria's oil fields and sold the oil in Syria and Iraq via brokers to local and international buyers (Steenkamp 2017).

In situations like the gasoline-cocaine flows across the borders that Colombia shares with Venezuela and Ecuador respectively, or the oil smuggling and interlinked businesses in Syria and across the border to Iraq, the side effects can be severe if the state engages in crackdowns against large-scale traffickers. Given the interconnectedness of flows, these measures may also interrupt survival smuggling or put small-scale smugglers at risk if they are stigmatized as whistle-blowers. Likewise, blocking (physical) routes through border closures, not only diverges (rather than disrupts) large-scale transnational organized criminal operations, but also disrupts local contraband, which is often rooted in the absence of legal livelihood options. As a result, local populations may develop or increase grievances against the state and feel more alienated from it while being drawn to the illicit armed actors because they may provide protection.

A common institutional context of illicit supply chain networks also includes strong state presence but little accountability; for example, when state officials are corrupt and hence decide to be selectively absent by turning a blind eye to the illicit business, or to participate in the illicit business themselves. States participate in illicit supply chain networks in various ways. Jonathan Kelman (2015) distinguishes among four types of participation: direct revenue generation; indirect revenue generation; procurement; and territorial control. With a slightly different emphasis, Gallien and Weigand (2021), distinguish among six types of relationships between states and smugglers, ranging from genuine enforcement to petty corruption. With the very authority designed to curb these flows in many cases becoming their promoter, the effectiveness and resilience of these networks becomes greatly enhanced. In this sense, the territorial state 
defined by state borders preconditions the institutional context in which illicit supply chain networks are most thriving.

Linked to the role of state officials in facilitating illicit supply chain networks is Williams and Godson (2002)'s argument that at least four political moments are conducive to the prosperity of these networks. The first political moment is when states with strong capacities become weaker because such a weakening process facilitates the corruption of the older elite. The second one concerns the transition from a command economy to a free market: in such cases, criminals in charge of illicit flows easily can gain control over parts of the licit economy, such as banks, as well, and thus operate in a grey zone between the underworld and the upperworld, with both licit and illicit flows operating on the same routes. A third moment are periods of armed conflict or when groups engage in terrorist attacks, armed actors use their expertise as entrepreneurs of violence for criminal ends, contributing to the illicit business. Fourth, after the signing of a ceasefire or a peace agreement, former (state and non-state) military leaders may aim to maintain power via controlling (parts of) illicit supply chain networks, or those armed groups that remain outside the agreement may strive to expand their income basis in the illicit economy.

\section{iv Governance structure}

The relationships of the actors involved shapes the governance structure of illicit supply chain networks. One or several (violent) groups - including both state and non-state actors - carry out or control each network activity (e.g., protection of production sites, domestic transport). In many cases, this division of labour yields territorial segmentation (Deville 2013, 65; see also Govindan, Fattahi, and Keyvanshokooh 2017, 112). ${ }^{10}$ The groups typically respect territorial limits of influence, within which each group exerts economic, social, and/or political control. ${ }^{11}$ Their presence is relatively localized in a particular place or node. This specialization maximizes profits from each supply chain step. These steps are interlinked through the relationships that these groups have with each other. They are also linked through little-known middlemen, socalled financiers, or more powerful brokers. In the case of natural resource extraction, financiers may buy the raw, or only minimally processed, material from the farmers or workers and ensure it reaches laboratories, where it is processed further. Especially in contexts of armed conflict, as is the case with the cocaine business in Colombia, or the heroin and opium business in Afghanistan and Myanmar, they operate where one group, for example an insurgent group, controls cultivation on its own, or where such a group subordinates others and engages at the "fringes" of that territory in stable arrangements with other groups, including state actors (Chouvy 2010; Mansfield 2016; Idler 2019). Powerful brokers negotiate among the parties, including over the final product.

The relatively clear division of labour that characterizes most elements of illicit supply chain networks does not hold at the intersections of trafficking flows. Here, economic interests of various non-state groups converge, but there is also competition, especially if more than two groups are present, or if one non-state group and the state, or state actors, compete. Even though, generally, they mistrust each other as rivals, on these particular occasions they reduce mistrust to be able to strike business deals such as drugs-for-arms barter agreements; they forge short-term arrangements. General mistrust persists however, so trafficking nodes are typically rife with selective violence targeted against actual and potential cheaters and betrayers. Often, the local population gets caught in the crossfire.

Brokers serve to strike deals in the case of more regular transactions. Brokers are perceived to be trustworthy and reliable by all groups involved, and they have networks across sectors in society: typically, they are connected with local political and economic elites, civil society, and 
armed actors. Examples of such brokers include alias Megateo, a former rebel leader who became the main intermediary of illicit supply chain networks centered on cocaine in Colombia. Heading the remaining faction of the otherwise demobilized Popular Liberation Army (EPL), he had links with the left-wing FARC-EP and ELN rebels, but also with rightwing groups. Local community members considered him a role model, as he was originally from the region and was considered to care for the locals. He connected the various links of the supply chain. After the Colombian state forces killed him in 2015, a power struggle around his replacement broke out. Filling that void took rather long because of the unique characteristics such an individual needs to possess (Idler 2020). Some of these brokers resemble a war lord, as did Megateo. Others resemble more closely an entrepreneur, for instance Victor Bout, imprisoned in the United States (Roth 2010, 150). He is known as a Russian arms dealer, supplying among others, multiple rebel groups in Africa and the Colombian FARC rebels with weapons. He is also known to have been involved in money laundering operations and in sales of aircraft and surface-to-air missiles. In brief, he connected various types of illicit flows and thus facilitated the smooth operating of illicit supply chain networks (Farah 2012; Farah and Braun 2010).

\section{Conclusion}

This chapter has demonstrated the importance of analyzing the interconnectedness of illicit flows rather than studying them individually in order to better understand how they operate, what their social, economic, and political implications are, and to identify possible entry points to tackle them. Conceptualizing the intersections of smuggling flows as trafficking nodes that form part of illicit supply chain networks shows their unique role in terms of the input-output structure, the institutional context, the territoriality, and the governance structure of these networks. They hold these networks together and, while bringing livelihood opportunities for local communities in locations that function as trafficking nodes, they also make these communities extremely vulnerable to abuse by both non-state and state actors.

The implications for the study of unstable regions where illicit flows intersect and of the illicit economy more broadly are clear. First, this chapter shows the need to challenge statecentric concepts to study the intersections of illicit flows because these flows reach across borders. Academic studies still tend to be organized as country (comparative) case studies, rather than as studies across borders. Considering transnational borderlands as starting points for research rather than adopting national perspectives on smuggling flows is crucial to overcome this bias. This has methodological implications. Students of smuggling face asymmetries in statecentric data sources, such as national statistics. Those who adopt an ethnographic approach across borders, for example through multi-sited fieldwork, deal with further complications, such as securing support networks, visa, and research permits across borders. Future work needs to address both the conceptual shift and discuss ways to address these methodological challenges. ${ }^{12}$ Second, we must map the interconnectedness of illicit supply chain networks to identify disruptors rather than focus on individual supply chain links. This includes centering scholarly attention on the mechanisms that link different supply chain networks instead of focusing on individual flows in isolation. Scholarship to date has mostly focused on the most salient or most lucrative type of smuggling in a given region, thereby neglecting how less profitable, or less sensational interconnected flows drive the overall network. Conceptualizing smuggling flows as illicit supply chain networks in which multiple flows of different types of goods are interconnected helps address this issue. For example, rather than focusing on cocaine trafficking only in South America, enhancing understanding of the flows of chemical precursors 
that are used to process coca leaves into cocaine is an important entry point to grasp the extension and functioning of the overall cocaine supply chain network. Third, we need to study the moral economy of illicit supply chain networks, not just the political economy to understand the role that these networks have for people's daily lives. Where legal livelihood opportunities are scarce, what is legitimate does not necessarily map on to what is legal. This has consequences for entire interrelated legal and illegal, and formal and informal markets.

These implications for the study of intersecting smuggling flows yield important practical considerations. "State solutions" may not necessarily work. Scrutinizing local perceptions and experiences of people living in locations of trafficking nodes demonstrates that a law enforcement approach may not only be ineffective, it can also put people at risk. This does not mean that hierarchical state bureaucracies are necessarily ill-equipped to counter illicit cross-border networked organizations that are embedded in local communities. Rather, these characteristics need to be accounted for (Eilstrup-Sangiovanni and Jones 2008). We need to anticipate the implications of disruptions for the moral economy. As the analysis with a view to the institutional context of illicit supply chain networks shows, measures to thwart illicit interlinked networks may undermine people's licit livelihood strategies: discouraging the trafficking of illicit goods via such routes must come along with protecting and promoting legal commerce in order not to jeopardize people's economic and food security. Ultimately, any investment needs to be holistic and inclusive of local communities to drain the support to illicit networks.

\section{Acknowledgements}

The author would like to thank Florian Weigand and Max Gallien for helpful comments on earlier drafts of this chapter.

\section{Notes}

1 For an overview of various different illicit flows, see Nellemann et al. (2018).

2 For the distinction between cyber-assisted, cyber-enabled, and cyber-dependent crime see Wall (2017, 1081).

3 I borrow from the global commodity chain literature (see, e.g., Gereffi and Korzeniewicz 1994; Bair 2005). For discussions of supply chain networks in the licit economy see for example Govindan, Fattahi, and Keyvanshokooh (2017); Klibi and Martel (2012); Snyder et al. (2006).

4 For interconnectedness see Dicken et al. (2001, 91).

5 Interview by the author with the police commander of a remote, violence-affected town in Colombia, 2012.

6 For the role of locality and place in supply chains see Bair $(2005,159)$.

7 There is some flexibility, as the existence of mobile cocaine processing laboratories, for instance, demonstrates (Idler 2019, 261).

8 This is not necessarily the case for money laundering and for transactions that take place in cyberspace.

9 Smuggling dynamics have since reversed: it became more common for gasoline to be smuggled from Colombia into Venezuela.

10 In the case of the cocaine industry, in the 1980s and 1990s this spatial division of labour concerned even countries: Bolivia and Peru hosted the cultivation and harvesting of coca leaves, and their processing into coca paste; Colombia hosted further processing, trafficking, and the starting points for international export (Gootenberg 2012, 169).

11 Markers such as graffiti, pamphlets, or flags, or practices such as charging protection money define these limits. The operational territories of violent non-state groups often coincide with an urban-rural divide. See Tickner, García, and Arrezea (2011); Laverde and Tapia (2009).

12 See Idler (2019, Appendix A) for ways to address some of these challenges. 


\section{References}

Abraham, Itty, and Willem van Schendel. 2005. "Introduction: The Making of Illicitness." In Illicit Flows and Criminal Things: States, Borders, and the Other Side of Globalization, edited by Willem van and Abraham Schendel, 1-37. Bloomington: Indiana University Press.

Andreas, Peter. 2003. "Redrawing the Line: Borders and Security in the Twenty-First Century." International Security 28: 78-111.

Andreas, Peter. 2009. Border Games: Policing the U.S.-Mexico Divide. 2nd ed. Ithaca: Cornell University Press.

Andreas, Peter. 2014. Smuggler Nation: How Illicit Trade Made America. New York: Oxford University Press.

Andreatta, Daniela, and Serena Favarin. 2020. "Features of Transnational Illicit Waste Trafficking and Crime Prevention Strategies to Tackle It." Global Crime 21(2): 130-153. https://doi.org/10.1080/ 17440572.2020.1719837.

Arias, Enrique Desmond, and Thomas Grisaffi. 2021. "Introduction." In The Governance of the Global Narcotics Trade, edited by Enrique Desmond Arias and Thomas Grisaffi.

Bair, Jennifer. 2005. "Global Capitalism and Commodity Chains: Looking Back, Going Forward." Competition \& Change 9(2): 153-180. https://doi.org/10.1179/102452905X45382.

Brenner, Neil. 1999. "Beyond State-Centrism? Space, Territoriality, and Geographical Scale in Globalization Studies." Theory and Society 28(1): 39-78. https://doi.org/10.1023/A:1006996806674.

Castells, Manuel. 2010. End of Millennium. 2nd ed. Oxford: Wiley-Blackwell.

Chapkis, Wendy. 2003. "Trafficking, Migration, and the Law: Protecting Innocents, Punishing Immigrants." Gender \& Society 17(6): 923-937. https://doi.org/10.1177/0891243203257477.

Chouvy, Pierre-Arnaud. 2010. Opium: Uncovering the Politics of the Poppy.1st ed. Cambridge, MA: Harvard University Press.

Christopher, Martin. 1998. Logistics and Supply Chain Management: Strategies for Reducing Cost and Improving Service. 2nd ed. London: Financial Times/Pitman.

Clunan, Anne L., and Harold A. Trinkunas, eds. 2010. Ungoverned Spaces: Alternatives to State Authority in an Era of Softened Sovereignty. Stanford: Stanford University Press.

Deville, Duncan. 2013. "The Illicit Supply Chain." In Convergence: Illicit Networks and National Security in the Age of Globalization, edited by Michael Miklaucic and Jacqueline Brewer, 63-74. Washington, DC: National Defense University.

Dicken, Peter, Philip F. Kelly, Kris Olds, and Henry Wai-Chung Yeung. 2001. "Chains and Networks, Territories and Scales: Towards a Relational Framework for Analysing the Global Economy." Global Networks 1(2): 89-112. https://doi.org/10.1111/1471-0374.00007.

Eilstrup-Sangiovanni, Mette, and Calvert Jones. 2008. "Assessing the Dangers of Illicit Networks: Why alQaida May Be Less Threatening Than Many Think." International Security 33(2): 7-44. https:// doi.org/10.1162/isec.2008.33.2.7.

European Monitoring Centre for Drugs and Drug Addiction, and Europol. 2019. "EU Drug Markets Report 2019." Luxembourg: Publications Office of the European Union. https://www.emcdda. europa.eu/system/files/publications/12078/20192630_TD0319332ENN_PDF.pdf.

EUROPOL. 2018. "Internet Organised Crime Threat Assessment." EUROPOL. https:// www.europol.europa.eu/activities-services/main-reports/internet-organised-crime-threat-assessmentiocta-2018.

Farah, Douglas. 2012. "Fixers, Super Fixers and Shadow Facilitators: How Networks Connect." International Assessment and Strategy Center. https://cco.ndu.edu/Portals/96/Documents/Articles/ Fixers_Super-Fixers_and_Shadow_Facilitators_Farah.pdf.

Farah, Douglas, and Stephen Braun. 2010. Merchant of Death: Money, Guns, Planes, and the Man Who Makes War Possible. Chichester: Wiley.

Friman, H. Richard, and Peter Andreas. 1999. The Illicit Global Economy and State Power. Lanham, MD; Oxford: Rowman \& Littlefield Publishers.

Gallien, Max. 2020. "Informal Institutions and the Regulation of Smuggling in North Africa." Perspectives on Politics 18(2): 492-508. https://doi.org/10.1017/S1537592719001026.

Gallien, Max, and Florian Weigand. 2021. "Channeling Contraband: How States Shape International Smuggling Routes.” Security Studies 0(0): 1-28. https://doi.org/10.1080/09636412.2021.1885728.

Gereffi, Gary, and Miguel Korzeniewicz. 1994. Commodity Chains and Global Capitalism. Westport, CT; London: Praeger. 
Gootenberg, Paul. 2012. “Cocaine's Long March North, 1900-2010.” Latin American Politics and Society 54(1): 159-180. https://doi.org/10.1111/j.1548-2456.2012.00146.x.

Govindan, Kannan, Mohammad Fattahi, and Esmaeil Keyvanshokooh. 2017. "Supply Chain Network Design under Uncertainty: A Comprehensive Review and Future Research Directions." European Journal of Operational Research 263(1): 108-141. https://doi.org/10.1016/j.ejor.2017.04.009.

Hägerdal, Nils. 2019. "Toxic Waste Dumping in Conflict Zones: Evidence from 1980s Lebanon." Mediterranean Politics 26(2): 198-218. https://doi.org/10.1080/13629395.2019.1693124.

Herbert, Matt, and Max Gallien. 2020. "A Rising Tide: Trends in Production, Trafficking and Consumption of Drugs in North Africa." Global Initiative against Transnational Organized Crime. https://globalinitiative.net/wp-content/uploads/2020/06/A-rising-tide-trends-in-production-trafficking-and-consumption-of-drugs-in-North-Africa-GITOC.pdf.

Idler, Annette. 2017. “The Future of International Security: Challenges for Responses to the World's Changing Security Landscape.” Discussion Paper. World Economic Forum's Global Future Council on International Security. https://conflictplatform.ox.ac.uk/cccp/research/the-future-of-internationalsecurity-challenges-for-responses-to-the-worlds-changing-security-landscape.

Idler, Annette. 2019. Borderland Battles: Violence, Crime, and Governance at the Edges of Colombia's War. New York: Oxford University Press

Idler, Annette. 2020. "The Logic of Illicit Flows in Armed Conflict: Explaining Variation in Violent Nonstate Group Interactions in Colombia." World Politics 72(3): 335-376. https://doi.org/10.1017/ S0043887120000040.

Idler, Annette. 2021. "Warriors, Victims, and Vulnerable Regions: A Critical Perspective on the War on Drugs." In Transforming the War on Drugs, edited by Annette Idler and Juan Carlos Garzón Vergara. London: Hurst Publishers. https://www.hurstpublishers.com/book/transforming-the-war-on-drugs/.

The Investigative Project on Terrorism. 2018. "US v. Cardona-Cardona, et Al.:" The Investigative Project on Terrorism. https://www.investigativeproject.org/case/881/us-v-cardona-cardona-et-al.

Katersky, Aaron. 2019. "Man Charged in Alleged Drugs-for-Weapons Deal with al-Qaeda-Linked Group.” ABC News, January 18, 2019. https://abcnews.go.com/US/man-charged-alleged-drugsweapons-deal-al-qaeda/story?id=60471639.

Kelman, Jonathan H. C. 2015. "States Can Play, Too: Constructing a Typology of State Participation in Illicit Flows." Crime, Law and Social Change 64(1): 37-55. https://doi.org/10.1007/s10611-015-95 68-4.

Klibi, Walid, and Alain Martel. 2012. "Scenario-Based Supply Chain Network Risk Modeling." European Journal of Operational Research 223(3): 644-658. https://doi.org/10.1016/j.ejor.2012.06.027.

Laverde, Zully, and Edwin Tapia. 2009. Tensión En Las Fronteras. Bogotá, Colombia: CODHES.

Lexico Oxford Dictionary. 2020. "Meaning of Globalization in English.” 2020. https://www.lexico.com/ definition/globalization.

Lusthaus, Jonathan. 2013. "How Organised Is Organised Cybercrime?” Global Crime 14(1): 52-60. https://doi.org/10.1080/17440572.2012.759508.

Mansfield, David. 2016. A State Built on Sand: How Opium Undermined Afghanistan [Electronic Resource]. Ebook Central. New York, New York: Oxford University Press. https://ezproxy-prd.bodleian.ox.ac.uk/login? url=https://ebookcentral.proquest.com/lib/oxford/detail.action?docID=4803072.

Martin, James. 2014. "Lost on the Silk Road: Online Drug Distribution and the 'Cryptomarket."' Criminology \& Criminal Justice 14(3): 351-367. https://doi.org/10.1177/1748895813505234.

Micallef, Mark, and Tuesday Reitano. 2017. “The Anti-Human Smuggling Business and Libya's Political End Game." Global Initiative against Transnational Organized Crime, Institute for Security Studies, North Africa Report, 2 (December): 24.

Naím, Moisés. 2007. Illicit. London: Arrow.

Nellemann, Christian, Jürgen Stock, Mark Shaw, International Criminal Police Organization, RHIPTO, and Global Initiative Against Transnational Organized Crime. 2018. World Atlas of Illicit Flows. http:// globalinitiative.net/wp-content/uploads/2018/09/Atlas-Illicit-Flows-FINAL-WEB-VERSION-copiacompressed.pdf.

Ōmae, Ken'ichi. 1990. The Borderless World: Power and Strategy in the Interlinked Economy. London: Collins.

Pokoo, John M., and Kwesi Aning. 2021. "West Africa-Securitized Drugs as an Existential Threat." In Transforming the War on Drugs | Hurst Publishers, edited by Annette Idler and Juan Carlos Garzón Vergara. London: Hurst Publishers. https://www.hurstpublishers.com/book/transforming-the-waron-drugs/. 
Prince, Daniel. 2016. “The Dark Web: What It Is and How It Works.” World Economic Forum (blog). 2016. https://www.weforum.org/agenda/2016/10/the-dark-web-what-it-is-and-how-it-works/.

Reitano, Tuesday, and Mark Shaw. 2017. "The Politics of Power, Protection, Identity and Illicit Trade." Crime-Conflict Nexus Series 3. United Nations University Centre for Policy Research.

Robins, Philip. 2021. "The Crescent Three States-Which Way to Go?” In Transforming the War on Drugs | Hurst Publishers, edited by Annette Idler and Juan Carlos Garzón Vergara. London: Hurst Publishers. https://www.hurstpublishers.com/book/transforming-the-war-on-drugs/.

Roth, Mitchel P. 2010. Global Organized Crime: A Reference Handbook. ABC-Clio.

SAT, Sistema de Alertas Tempranas. Defensoría del Pueblo de Colombia. 2012. "Informe de Riesgo No 024-12." Bogotá, Colombia: Defensoría del Pueblo de Colombia.

Schendel, Willem van. 2005. "Spaces of Engagement: How Borderlands, Illicit Flows, and Territorial States Interlock." in Schendel, Willem van, and Itty Abraham, eds. 2005. Illicit Flows and Criminal Things: States, Borders, and the Other Side of Globalization. Bloomington: Indiana University Press, 38-68.

Schendel, Willem van, and Itty Abraham, eds. 2005. Illicit Flows and Criminal Things: States, Borders, and the Other Side of Globalization. Bloomington: Indiana University Press.

Snyder, Lawrence V., Maria P. Scaparra, Mark S. Daskin, and Richard L. Church. 2006. "Planning for Disruptions in Supply Chain Networks." In Models, Methods, and Applications for Innovative Decision Making, 234-257. INFORMS TutORials in Operations Research. INFORMS. https://doi.org/10.12 87/educ.1063.0025.

Solomon, Erika. 2015. "Isis: The Munitions Trail." Financial Times, November 30, 2015. https:// www.ft.com/content/baad34e4-973c-11e5-9228-87e603d47bdc.

Steenkamp, Christina. 2017. "The Crime-Conflict Nexus and the Civil War in Syria." Stability: International Journal of Security and Development 6(1): 11. https://doi.org/10.5334/sta.522.

Tickner, Arlene B., Diego García, and Catalina Arrezea. 2011. "Actores Violentos No Estatales y Narcotráfico En Colombia." In Políticas Antidroga En Colombia: Éxitos, Fracasos y Extravíos, 1. ed, 413-445. Bogotá, DC, Colombia: Universidad de los Andes.

Tilly, Charles. 1985. "War Making and State Making as Organized Crime." In Bringing the State Back In, edited by Peter B. Evans, Dietrich Rueschemeyer, Theda Skocpol, Structures Social Science Research Council. Committee on States and Social, Studies Joint Committee on Latin American, and Europe Joint Committee on Western, 169-191. Cambridge: Cambridge University Press.

United Nations, and World Bank. 2018. "Pathways for Peace: Inclusive Approaches to Preventing Violent Conflict." Washington, DC: World Bank. http://hdl.handle.net/10986/28337.

UNODC. 2018. "World Drug Report 2018." Vienna: UNODC.

Wall, David S. 2017. "Crime, Security, and Information Communication Technologies." The Oxford Handbook of Law, Regulation and Technology. July 20, 2017. https://doi.org/10.1093/oxfordhb/97801 99680832.013.65.

Williams, Phil, and Roy Godson. 2002. "Anticipating Organized and Transnational Crime." Crime, Law and Social Change 37(June): 311-355. https://doi.org/10.1023/A:1016095317864. 